\title{
Unpacking Barriers to Socially Inclusive Weather Index Insurance: Towards a Framework for Inclusion
}

\author{
Mohamed Aheeyar*(D), Sanjiv de Silva, Sonali Senaratna-Sellamuttu and Indika Arulingam \\ International Water Management Institute, Battaramulla 10120, Sri Lanka; s.s.desilva@cgiar.org (S.d.S.); \\ s.senaratnasellamuttu@cgiar.org (S.S.-S.); I.Arulingam@cgiar.org (I.A.) \\ * Correspondence: M.Aheeyar@cgiar.org
}

Received: 14 September 2019; Accepted: 16 October 2019; Published: 25 October 2019

\begin{abstract}
Floods account for a majority of disasters, especially in South Asia, where they affect 27 million people annually, causing economic losses of over US $\$ 1$ billion. Climate change threatens to exacerbate these risks. Risk transfer mechanisms, such as weather index insurance (WII) may help buffer farmers against these hazards. However, WII programs struggle to attract the clients most in need of protection, including marginalized women and men. This risks re-enforcing existing inequalities and missing opportunities to promote pro-poor and gender-sensitive development. Key questions, therefore, include what factors constrain access to WIIs amongst heterogeneous communities, and how these can be addressed. This paper contributes to that end through primary data from two WII case studies (one in India, the other in Bangladesh) that identify contextual socio-economic and structural barriers to accessing WII, and strategies to overcome these. More significantly, this paper synthesizes the case study findings and those from a review of the literature on other WII initiatives into a framework to promote a systematic approach to address these challenges: an important step forward in moving from problem analysis to remedial action. The framework highlights actions across WII product design, implementation and post-implementation, to minimize risks of social exclusion in future WII schemes.
\end{abstract}

Keywords: floods; climate change; resilience; index-insurance; social inclusion; gender; equity; equality

\section{Introduction}

South Asian countries are highly prone to natural disasters, and over the past 40 years, floods accounted for approximately half of all disasters, affecting on average of approximately 27 million people annually. Floods were responsible for $80 \%$ of all economic loss caused by disasters in the region, with an annual average of over US $\$ 1$ billion [1]. The risk of flood-induced loss of life and property is highest in India and Bangladesh [2]. Climate change is expected to exacerbate these risks. The intensities of flooding and other natural disaster's impacts in South Asia are also linked to the high dependence on smallholder agriculture for livelihoods, where disasters disproportionately affect marginal and smallholder farmers who lack the wherewithal to deal with damage and loss of income-earning opportunities. This includes women, who tend to be among the poorest and the most vulnerable to climate change and weather shocks [3,4]. At stake, therefore, are the livelihoods of millions of small and marginal farmer households, and national Sustainable Development Goal (SDG) targets, including those linked to poverty reduction (SDG 1); food and nutrition security (SDG 2); and gender (SDG 5).

Contributing to small-scale farmers' vulnerability in developing countries is an insufficiency of state protection against climatic and other risks [5-7], resulting in deepening cycles of debt, since cultivation is often financed by borrowing. The capacity of poor and vulnerable farmers to cope and avail 
themselves of government flood relief is especially limited because they lack information and political capital within local political economies. While various governments have adopted different adaptation strategies to minimize climate change's impacts, attention to social equity issues have often been missed [8]. (Fisher et al., 2018 [9] highlights the distinction between equity and equality. They articulate equality as being the same or being treated equally, while equity is related to whether people are treated fairly. They argue that focusing on social equity helps to consider how social difference and associated inequalities may affect poor people's access to index insurance, and how insurance design and its implementation can contribute to the distribution of fair or equal developmental outcomes. They further importantly recognize, that given social heterogeneity, insurance schemes may need to treat differently-capacitated people in different ways to effect equal outcomes). This suggests current technocratic approaches may favor elites at the expense of the more vulnerable and least socially, economically and politically empowered groups.

Weather index insurance WII products are seen by some as a potential solution to buffer farmers against increasing, climate-induced risks (but not all; see $[7,10]$ who warn that the structure of insurance schemes in the agricultural sector can also equally exacerbate smallholder vulnerabilities). They are presented as pro-poor initiatives that expand opportunities for smallholders who are often excluded from insurance markets, a form of 'poverty capital' [11]. WII offers policyholders a payout depending on some external weather-related indicator highly correlated with crop yields, such as rainfall and temperature, which triggers a payment to all insured clients within a geographically-defined space at the pre-defined indexes that were developed (based on the relationship to crop yield and selected weather indicator) by the insurance program. Such insurance schemes have performed well in terms of covering revenue losses in most of the extreme events observed in developing countries [12]. WII is attractive in low-income countries because it has the potential to address correlated risk affordably [13]. In addition, WII products enable farmers to take on more risk in production while reducing the costs for insurance companies by minimizing labor overheads when monitoring individual farms and loss assessment [14,15].

However, reaching remote and diverse communities with technically complex index insurance products is an enormous challenge [13]. Both conventional and index-based crop insurance schemes have failed to live up to the pro-poor hype $[7,16]$, being largely biased towards larger farmers. The adoption of a narrow technocratic focus has, subject to some exceptions, missed out the most vulnerable [16,17], including underrepresented female farmers [18-20]. Fisher et al. (2018:17) [9] succinctly capture these risks: "The allure of index insurance can mask issues of power, social inequality and differential impact in rural communities. The need to be cognizant of the danger of implicitly reinforcing inequality through the design and delivery of index insurance underlines how more consideration needs to be given to the way uptake of index insurance is shaped by existing inequalities and, in turn, how these inequalities contribute to differential development outcomes for smallholder farmers/pastoralists".

Mitigating the risk of promoting inequity will, thus, require the architects of WII initiatives to recognize a social if not moral responsibility beyond standard insurance practices, to acknowledge the heterogeneity of communities, and actively consider the realities of the targeted beneficiaries through a deeper understanding of their respective social, cultural, institutional and economic contexts and preferences.

This paper contributes to alleviating these risks through two pathways. Using primary data from two case studies of WII pilots and results from a desk review of literature on other WII initiatives, this paper first unpacks what localized obstacles different stakeholders face when accessing WII schemes. Considering and contrasting how social diversity issues were addressed in the two case studies and other WII schemes cited in the literature, the paper then develops recommendations for how gaps between local contextual challenges and current WII designs and roll-out mechanisms may be bridged. This represents a stock-take of current experiences with respect to inclusivity in WII schemes to date. The more significant contribution of this paper, however, lies in its synthesis 
of this knowledge into a framework for systematically sensitizing the product design, rollout and post-rollout stages of a WII scheme to the diverse needs and capabilities of potential WII beneficiaries. It is posited that such a framework represents a necessary and hitherto missing step to move from problem analysis to an informed and structured pathway to incorporate past lessons into future WII initiatives. For example, since the framework identifies how various stages of a WII scheme could be modified, it provides a useful platform to engage the financiers of WII (private insurance companies, governments and donors) on how the proposed additional features to the WII scheme could be affected, not least financed.

\section{Study Sites}

\subsection{Bihar State, India}

About $81 \%$ of Bihar's 108.1 million population belong to farmer households. Average literacy in Bihar is $63.8 \%$, compared to $74 \%$ for India, with $53 \%$ of females and $73 \%$ of males being able to read and write with understanding [21]. About $80 \%$ of Bihar's farmers are small and marginal, having an average landholding of 0.4 ha in 2016 (small farmers in India cultivate $0.5-2.5$ acres (0.2-1 ha), and marginal farmers cultivate less than 0.5 acre ( 0.2 ha) of land [19]. Female-headed households comprise $10 \%-12 \%$ of total households. This percentage is rising in rural India because of widowhood, desertion and male out-migration [22]. Female-headed households together with other disadvantaged groups, such as scheduled castes and scheduled tribes (SC and ST) and ethnic minorities, comprise $48 \%$ of Bihar's population [21]. (The Scheduled Castes (SCs) and Scheduled Tribes (STs) are officially designated groups of historically disadvantaged people in India. To achieve sustainable and more inclusive growth, special efforts are needed to address the issues of the poor, the Scheduled Castes, the Scheduled Tribes, other backward classes, minorities, differently abled and other marginalized groups (Source: UN India, http://in.one.un.org/task-teams/scheduled-castes-and-scheduled-tribes)). A major impediment to Bihar's agriculture is the multiple and frequent disasters, predominantly floods and droughts, with $73.63 \%$ of North Bihar considered to be flood-prone.

One of the WIIs informing this paper is an index-based flood insurance product implemented in parts of Bihar by the International Water Management Institute (IWMI). By integrating high-tech computer modeling, satellite imaginary, and Geographical Information System (GIS) technology, this insurance model uses predetermined flood thresholds to trigger speedy compensation payouts $[23,24]$. This approach is considered both cost-effective and able to better target post-disaster relief to compensate for agricultural losses. The product was piloted during the Kharif (the cropping season spanning July-October during the south-west monsoon) seasons of 2017 and 2018 in partnership with the state government and private insurance organizations. Farmers who had proof of their identity (voter card, identity card, driving license, etc.), proof of address, land documents to attest to cultivation and a bank account, were eligible to enroll in the first pilot. Payout triggers were predetermined based on flood height and the duration of inundation. The floods triggered the payout in two out of five villages in 2017 and two out of 11 pilot villages in 2018. Compensation was transferred directly to the individual bank accounts with no requirement for intermediaries [25,26].

\subsection{Sirajganj District, Bangladesh}

Bangladesh is one of the world's most densely populated countries. Agriculture is the largest economic sector and accommodates around $42.7 \%$ of the country's labor force. About $85 \%$ of agricultural land holdings are less than one hectare [27], and over $50 \%$ of households are classified as landless, as they own under 0.5 acres (0.2 ha) (Agricultural Census of Bangladesh, 1996/97 cited in Salman et al [28]. Unlike other countries in South Asia, Bangladesh's predominantly rural society has a high degree of linguistic, religious and ethnic homogeneity, although small ethnic minorities (tribal groups) and a large Hindu minority exist [29]. The literacy rate of the total population is 59.1\%. Women's literacy is $56.9 \%$ while men's is $61.3 \%$ [30]. Crop loss due to frequent, numerous natural 
disasters is a regular phenomenon. There were 71 major floods in Bangladesh during 1980-2015 affecting over 250 million people, with an estimated economic loss of over USD 14.5 billion [31]. Salman et al (2010) [28] noted that design and implementation of agricultural insurance products tailored to address the needs of landless sharecroppers particularly, and tenant farmers and marginal and small landowners, is a major challenge.

The case study in Bangladesh is of a three-year (2015-2017) government and NGO WII pilot scheme in Sirajganj district that offered insurance for crops across both the Aman (wet) and Boro (dry) seasons. It was funded by the Asian Development Bank (ADB) and the government, which integrates flood depth and duration to determine crop damage. It was implemented by a consortium of partners including the Department of Meteorology; the International Network of Alternative Financial Institutions (INAFI); the National Development Program (NDP)—the micro-finance institution (MFI) that provided the grassroots networks for implementing the scheme; and the Sadharan Bima Corporation, the government-owned insurance company. The business case for the MFI is based on the presumption that the MFI can recover any loans from the insurance payout. The government subsidized the premium by $50 \%$.

Flooding is the main weather risk in Sirajganj, since much of the farmland is lowland. Focus group discussions (FGDs) with farmers suggest that the landless and small/marginal farmers are the most exposed in terms of the depth and duration of flooding, with few alternate livelihood options. Small and marginal farmers comprise between $58 \%$ and $72 \%$ of all farmers in the villages studied (Goyal Gram, Nur Nagar and Seyed Gati), while landless farmers constituted another $12 \%$ to $16.2 \%$.

\section{Method}

\subsection{Case Studies in India and Bangladesh}

Primary data was collected for each case study through a questionnaire survey, FGDs, in-depth interviews and key informant interviews (KII) representing different farmer classes; farmers who did and did not purchase insurance and/or receive a pay-out; women (farmers and non-farmers); local government and line agency representatives; and project personnel. Qualitative data collection in Sirajganj occurred in 2017 (Table 1), while sample surveys and qualitative assessments in Bihar were conducted in 2018 and 2019, each following an insurance pay-out. The randomly selected sample surveys (Table 2) were followed up by FGDs (Table 3) in Bihar. In each case study, the following aspects were explored: (i) gendered characterization of the target communities in terms of farmer classes; exposure to floods and other weather-related risks; prior experience with WIIs; and literacy; (ii) how diverse local contextual characteristics have impacted access to WII; (iii) the role of local institutions; and (iv) strategies and tools used to overcome challenges faced by different farmer groups, and their efficacy. The collected data was used to conduct descriptive analysis. No statistical analyses were conducted. 
Table 1. Dialogs held in Sirajganj, Bangladesh (2017).

\begin{tabular}{|c|c|c|c|c|c|c|}
\hline Respondents & FGD/KII & Men & Women & Location/Village & Union Parishad & Upazila \\
\hline Large farmers & FGD & 8 & 0 & Goyal Gram & Noygoan & Tarash \\
\hline Large farmers & FGD & 7 & 3 & Nur Nagar & Bhadragat & Kamarkhanda \\
\hline Marginal farmers & FGD & 10 & 0 & Goyal Gram & Noygoan & Tarash \\
\hline Marginal farmers & FGD & 6 & 6 & Seyed Gati & Bhdragat & Kamarkhanda \\
\hline Marginal farmers & FGD & 6 & 4 & Chuni hati & Kaliya Horipur & Sirajgonj Sader \\
\hline Land less farmers & FGD & 8 & 7 & Chuni Hati & Kaliya Horipur & Sirajgonj Sader \\
\hline Women & FGD & $\mathrm{N} / \mathrm{A}$ & 10 & Goyal Gram & Noygoan & Tarash \\
\hline Women & FGD & N/A & 10 & Chuni hati & Kaliya Horipur & Sirajgonj Sader \\
\hline Union Parishad members & FGD & 9 & 1 & Matia Buli para & Nawga & Tarash \\
\hline NDP field staff & In-depth & 2 & 1 & Seyed Gati & Bhdragat & Kamarkhanda \\
\hline Total $(140)^{1}$ & & 87 & 53 & & & \\
\hline
\end{tabular}

Table 2. Sample size of Bihar pilots in 2018 and 2019.

\begin{tabular}{ccccc}
\hline \multirow{2}{*}{ Name of Pilot Village } & \multicolumn{2}{c}{2019} & \multicolumn{2}{c}{2018} \\
\cline { 2 - 5 } & $\begin{array}{c}\text { Sample Farmers } \\
\text { (Insured) }\end{array}$ & $\begin{array}{c}\text { Sample Farmers } \\
\text { (Not Insured) }\end{array}$ & $\begin{array}{c}\text { Sample Farmers } \\
\text { (Insured) }\end{array}$ & $\begin{array}{c}\text { Sample Farmers } \\
\text { (Not Insured) }\end{array}$ \\
\hline Ajitpur Bakuchi & 09 & 1 & - & - \\
Andama & 05 & - & - & - \\
Barri & 08 & 6 & - & - \\
Bhatgama & 14 & 1 & 19 & 10 \\
Gangeya & 18 & 11 & - & - \\
Harkhauli & 12 & 3 & - & - \\
Harpur & 14 & 3 & - & - \\
Kalyanpur & 8 & - & 13 & - \\
Ladaur & 17 & 6 & - & - \\
Madhopur & 9 & 7 & - & 10 \\
Patari & 7 & 4 & 21 & 10 \\
Madhurapatti & - & - & 12 & 10 \\
Belaur & - & - & 15 & $\mathbf{5 0}$ \\
Paga & - & - & 15 & $\mathbf{9 5}$ \\
Bagawatpur & - & - & & - \\
Grand Total & $\mathbf{1 1 2}$ & $\mathbf{3 8}$ & & - \\
\hline
\end{tabular}

Table 3. Details of Focus group discussions held in Muzaffarpur District, Bihar in 2018 and 2019.

\begin{tabular}{|c|c|c|c|c|}
\hline Pilot Village & Type of the Village & Type of the Group & $\begin{array}{l}\text { Participants } \\
\text { in } 2019\end{array}$ & $\begin{array}{c}\text { Participants } \\
\text { in } 2018\end{array}$ \\
\hline Ajitpur Bakuchi & Pay-out village in 2019 & $\begin{array}{ll}\text { - } & \text { Payout receivers (men) } \\
\text { - } & \text { Non-insured farmers }\end{array}$ & $\begin{array}{l}10 \\
02\end{array}$ & \\
\hline Andama & Non-pay-out village & $\begin{array}{ll}\text { - } & \text { Insured male farmers } \\
\text { - } & \text { Insured female farmers }\end{array}$ & $\begin{array}{l}04 \\
03\end{array}$ & - \\
\hline Barri & Non-pay-out village & $\begin{array}{ll}\text { - } & \text { Insured male farmers } \\
\text { - } & \text { Insured female farmers }\end{array}$ & $\begin{array}{l}12 \\
02\end{array}$ & - \\
\hline
\end{tabular}


Table 3. Cont.

\begin{tabular}{|c|c|c|c|c|}
\hline Pilot Village & Type of the Village & Type of the Group & $\begin{array}{l}\text { Participants } \\
\text { in } 2019\end{array}$ & $\begin{array}{l}\text { Participants } \\
\text { in } 2018\end{array}$ \\
\hline Bhatgama & $\begin{array}{l}\text { Pay-out village in } 2018 \\
\text { and } 2019\end{array}$ & $\begin{array}{l}\text { - Women headed households } \\
\text { - } \quad \text { Male farmers }\end{array}$ & $\begin{array}{l}05 \\
06\end{array}$ & $\begin{array}{l}05 \\
18\end{array}$ \\
\hline Madhurapatti & Pay-out village in 2018 & $\begin{array}{ll}\text { - } & \text { Pay-out receivers } \\
\text { - } & \text { Non-insured farmers }\end{array}$ & - & $\begin{array}{l}10 \\
07\end{array}$ \\
\hline Gangeya & Non-pay-out village & $\begin{array}{ll}\text { - } & \text { Insured male farmers } \\
\text { - } & \text { Insured female farmers }\end{array}$ & $\begin{array}{l}08 \\
03\end{array}$ & - \\
\hline Harkhauli & Non-pay-out village & $\begin{array}{ll}\text { - } & \text { Insured female farmers } \\
\text { - } & \text { Insured male farmers } \\
\text { - } & \text { Non-insured farmers }\end{array}$ & $\begin{array}{l}05 \\
04 \\
02\end{array}$ & - \\
\hline Harpur & Non-pay-out village & $\begin{array}{ll}\text { - } & \text { Insured female farmers } \\
\text { - } & \text { Insured male farmers }\end{array}$ & $\begin{array}{l}02 \\
03\end{array}$ & - \\
\hline Kalyanpur & Non-pay-out village & $\begin{array}{ll}\text { - } & \text { Insured male farmers } \\
\text { - } & \text { Non-insured female farmers }\end{array}$ & $\begin{array}{l}04 \\
02\end{array}$ & - \\
\hline Ladaur & Non-pay-out village & $\begin{array}{ll}\text { - } & \text { Insured male farmers } \\
\text { - Women headed households }\end{array}$ & $\begin{array}{l}15 \\
04\end{array}$ & - \\
\hline Madhopur & Non-pay-out village & - $\quad$ Insured male farmers & 08 & - \\
\hline Patari & Non-pay-out village & $\begin{array}{l}\text { - Mix of insured men and } \\
\text { female farmers }\end{array}$ & 09 & - \\
\hline Paga & Non-pay-out village & $\begin{array}{ll}\text { - } & \text { Insured farmers } \\
\text { - } & \text { Non-insured farmers }\end{array}$ & - & $\begin{array}{l}08 \\
06\end{array}$ \\
\hline
\end{tabular}

The case study findings were complemented by a desk study of current literature, which helped frame the case study findings within the overarching debate on the suitability of WII from a developmental perspective. Literature was sourced from bibliographic repositories and google scholar and google searches.

\subsection{Literature Review}

The literature review covered available literature on index-based insurance, especially linked to experiences from Asia, Africa and Latin America, and covered a range of climatic risks and livelihood activities. The literature was comprised of both peer-reviewed and other reports, sourced through global bibliographic, Google Scholar and Google searches. While these findings contribute to the framework we present, they also help validate the case study findings, given that the WII pilots in each case study ran for only two years. 


\subsection{Framework Development}

The framework proposed in this paper represents a synthesis of the case study and literature review results. It also builds on the social equity assessment framework for index insurance [9] by identifying specific actions needed at each step in developing and implementing a WII product.

\section{Results and Discussion}

In both case studies, interviews with agricultural line agencies and local NGOs confirmed that farmers receive little post-disaster support from their governments. In Sirajganj for instance, such support is limited to the supply of seeds free of cost, though often these do not appear to reach the targeted farmers. The analysis of land size of the insured farmers in the 2017 pilot in Bihar shows that $50 \%$ of the insured are relatively large landowners owning one ha or more of paddy land, while farmers owning less than 0.5 ha constituted only $15 \%$ of the total insured farmers, despite small and marginal farmers being in the majority. In the same pilot, female farmers insured represented $14 \%$. There were no insured farmers belonging to a Schedule Caste or Scheduled Tribe. Similarly, in Sirajganj, 25\% of large farmers interviewed purchased insurance, while only $10 \%$ of small and marginal farmers had done so; meanwhile, none of the women who were interviewed who owned or rented farmland purchased insurance. This section explores this variation to identify the often inter-related elements of contextual heterogeneity that influence differently positioned and empowered groups from firstly knowing an insurance scheme is available, to understanding and trusting it and finally to their ability to buy into it (Section 4.1). Section 4.2 then identifies strategies to mitigate these challenges, and finally Section 4.3 brings these together in a process-oriented framework to guide future WII schemes towards better consider social inclusion.

\subsection{Local Contextual Characteristics that Create Barriers to Inclusive WII Programming}

4.1.1. Illiteracy, Novelty and Restricted Mobility Drive Limited Awareness, Understanding and Trust in WII

The Bihar and Sirajganj case studies indicate a correlation between farmer class and gender with respect to awareness of the insurance product's availability, with this declining from large farmers to landless groups. In Sirajganj, all large farmers interviewed were aware of the product; most small/marginal farmers were aware; none of the landless were; and only $30 \%$ of women knew of the product (through their husbands). The varying literacy level was a significant underlying factor. In Sirajganj, over half of large farmers could read and sign their name, while between $10 \%$ and $30 \%$ were illiterate. In contrast, up to $70 \%$ of small/marginal farmers and $80 \%$ of landless farmers were illiterate. The findings in Bihar were similar, indicating also that a large percentage of farmers over the age of 60 were illiterate, and that literacy was lower for people belonging to lower castes. For women, restricted mobility associated with gender norms and local cultural practices, especially in Sirajganj, and exclusion from male-dominated informal agricultural social networks were additional challenges.

Even where individuals are aware of the insurance product, literacy influences their ability to understand its complex workings, illiteracy thereby increasing the perception of risk about the future return on their investment and compounding a pre-existing distrust of private companies. This is especially so among poorer and less formally educated farmers [32], where the product's conceptual complexity undermined willingness to invest by smallholders and female farmers in particular $[18,33]$ (Giné et al. 2008; Akter et al. 2016). Patt et al. (2009) [34] in fact believe that the trust of farmers in organizations providing insurance services is one of the most important determinants of insurance's demand in developing countries. The scenario in Sirajganj was similar: small, marginal and landless farmers' understanding of how the product worked lacked specificity about under what circumstances a payout would be triggered. Prior experience of insurance was also strongly correlated in Bihar, where $99 \%$ of the farmers insured were beneficiaries of past government insurance schemes, suggesting that these farmers could more easily understand the basic concepts of insurance. Also relevant are the 
innate differences between men and women with respect to trust and risk taking, where in general, women tend to make less risky choices [35,36], and are also less likely to trust others [33], although Weber et al. (2002) [37] recognize that the degree of risk aversion is likely to be highly sensitive to context.

The danger of poor understanding of the products reaches beyond enrollment to discontent when a payout is not received, in circumstances where farmers feel the weather conditions justified a payout [16]. This was the case among farmers in Bihar who were insured but did not receive a payout or only received partial compensation despite some crop damage. While project staff tried to inform farmers of how the payout is triggered, it was still necessary for staff to spend time post-payout to explain the gap between farmers' expectations and experience. This level of engagement, however, contrasts with more conventional insurance schemes where customers come to insurance providers. Most private insurance companies lack the institutional networks at the village level and the associated social science expertise needed to overcome negative farmer perceptions, and lack of knowledge of how WII schemes work [28]. As put by Johnson et al. (2019:14) [16], “Many commercial partners based in urban centers are ill-prepared to interface with rural and often illiterate customers, and low demand continues to thwart visions of rapid scales". Transaction costs of doing this will also be high since insurance companies often lack on-ground networks.

\subsubsection{Inability to Meet Eligibility Criteria}

Land title is perhaps the most fundamental criteria in WII's scope for excluding some of the most vulnerable farmers. The most obvious group at risk are the landless where farmers rely on land leasing or other types of tenure arrangements to access land for cultivation. In Bihar about $30 \%$ of farmers in the pilot villages are pure tenants (cultivating only rented land) and $50 \%$ are partial tenants having both owner-operated land and rented land [25]. Landed farmers may also struggle to produce their land title where a copy of the same is not in their possession. In such cases, they will need time and competency to complete the formalities involved in obtaining proof of title. Both may not be available, including for farmers who reside outside the village, and their relatives or friends who operate their land. In Sirajganj, marginal/small farmers were not always able to produce the relevant documents in time. Illiteracy, especially amongst the small/marginal and landless farmers, was an added impediment in meeting application criteria and deadlines.

\subsubsection{Poverty and the Affordability of the Premium}

Wealth was, as expected, a significant determinant of crop weather insurance demand. In Sirajganj, the majority of the insured were large farmers for whom the BDT250 (USD 3) premium was not a challenge, as they compared it with the BDT300/day (USD 3.6/day) they pay for an agricultural laborer. Small/marginal farmers felt BDT 100-150 (USD 1.2-1.8) would be more affordable, while BDT100 (USD 1.2) was preferred by the landless, since they finance all inputs and must pay $50 \%$ of the crop to the landlord. These findings reflect others such as that of Binswanger-Mkhize (2012) [38] who points out that larger farmers also have greater resources to finance premiums.

\subsubsection{Particular Constraints Faced by Women}

In the developing world, women and children are disproportionately affected by household-level shocks [39]. Women are overrepresented among the world's poor and vulnerable to climate change and weather shocks [33], and therefore, may benefit disproportionately from improved risk management [40]. The social norms and institutions that render women's physical, social and economic risk different to those of men may, at the same time, undermine their access to innovative products intended to mitigate the long-term detrimental effects of shocks. This results in a low demand reported for these products among women [36]. Critics consequently argue that WIIs are generally designed for men, and that they fail to account for gender-specific needs and constraints [41]. WII pilot programs, therefore, place increasing emphasis on attracting female farmers. FGDs with women in Sirajganj (Table 3) appear to 
confirm that crop loss affects women directly through the loss of labor and income opportunities during the post-harvest period, and indirectly if a household has to reduce food consumption, where gender norms dictate that men and boys are prioritized. Therefore, women's ability to purchase insurance or influence men's decisions on whether or not to do so are critical for women's well-being in times of crop loss. Around 80\% of women interviewed on average in Bihar in 2017 and 2018, stated agricultural decisions are made by the male head of a household based on his views, and when issues are discussed, the views of the sons are more important than those of women. The dominance of men in agricultural decision-making also means women are generally less financially literate and have fewer key financial skills and less confidence [42]. This translates into greater difficulties in understanding the trigger levels and compensation mechanisms associated with WII [33].

The impacts of no safety-net intensify for women in small/marginal and landless households. Women interviewed from such households indicated that, in addition to further borrowing and seeking temporary employment elsewhere, their households are forced to sell their rice stock; reduce their daily meals from 3 to 2; and consume less or no protein [43]. Women will consume only the remaining food after the men and boys have eaten [43]. Not surprisingly, about half of the women who participated in the women-only FGDs (Table 3) interviewed in Sirajganj whose husbands had not purchased insurance were keen that their husbands purchase insurance in the next season. These women were even prepared to finance premium purchase using their savings, by taking a loan from a neighbor, or by selling poultry. While no conclusions can be drawn from this, it does pose the question of whether the better targeting of women could directly (female purchasing) and indirectly (women convincing the male decision-makers) increase demand for WII. Bageant and Barrett (2017) [39], in a review of existing experiences in pastoralist environments conclude the evidence to be inconclusive, given examples where this has and has not occurred. The reasons may link back to lack of financial literacy underpinned by generally lower formal education [32], and women's exposure to loss of income and production as a result of caring for sick children that is not covered by WII [20,44].

Some observers, such as Miles and Wiedmaier-Pfister (2018) [36], argue that women's vulnerabilities, needs, preferences and agency contexts are so different to those of men that WII products targeting women only may be more effective than trying to catch them with an all-inclusive single product. Even in such instances, the issues discussed in this paper will have relevance. However, whatever the approach is to involve women, it must be recognized that an insurance pay-out may not always maintain a household's food intake, if it is all spent on financing the next crop. Underlying this issue is the dominant role men appear to play in decision making over how payouts are spent, and it may be deduced that since they will prioritize future crop security, spending on food is not perceived as a priority. (See Chiappori and Donni (2009) [45]; Bageant and Barrett (2017) [39]; and Johnson et al. (2019) [16] amongst others for a discussion on factors affecting women's agency in household decision-making). This is, however, an issue beyond the remit of these insurance schemes.

\subsection{Potential Strategies to Mitigate Local Contextual Barriers}

4.2.1. Embed WII Design in Local Contexts and Heterogeneous Stakeholder Preferences to Optimize Accessibility and Uptake across Farmer Groups

The treatment of target communities as homogeneous is a common weakness amongst WIIs $[10,16,17]$, and many equity problems flow from this initial blindness to social differentiation and complexity. Informing WII design of contextual variables can be achieved in many ways, from group and individual discussions and interviews across the cross-section of male and female stakeholders, to more elaborate means, such as experimental games that can elicit clarity on diverse farmers' risk perceptions and preferences on types and levels of risk to be covered [9]. The key point, however, is that the actors driving WII invert their current approach by starting from an understanding of who really needs insurance and for what, rather than implementing largely pre-determined WII schemes. In fact, Greatrex et al. (2015:23) [12] concluded that, "All of the projects that engaged in meaningful discussions with farmers reported large benefits to index design and uptake", while Zevenbergen (2014) [46] found a strong 
demand by farmers in India to be involved in the product's design process; while this clearly has implications for transaction costs at both design and implementation stages (the commercial viability of the past insurance schemes was largely determined by the delivery cost $[47,48])$, it may be argued it is a necessary compromise given the risks of excluding the most vulnerable. Through their review of several large insurance schemes, Fisher at al. (2018) [9] make clear that with appropriate innovative approaches, marginal groups can be effectively reached. Moreover, as described below, these costs can be minimized if the right partnerships are identified.

Miles and Wiedmaier-Pfister (2018) [36] show that embedding the product in local context also needs to extend to post-rollout to monitor participation in the scheme and impacts on beneficiaries. This included sex-disaggregated data on enrolment and who received payouts; attendance at events to build awareness and understanding of the products; and changes in beneficiary attitudes. The data enabled the quantification of benefits and their distribution across the client base, and linked the schemes to a sense of enhanced empowerment amongst the female beneficiaries, and their greater investment in agriculture.

4.2.2. The Use of Multimedia and Localized Social Spaces to Ensure All Farmer Classes, Including Women, are Aware of the Product and Understand It

Patt et al. (2009) [34] suggest that demand for insurance can be increased through promotional and educational efforts, better product design and appropriate marketing to reduce misunderstanding and distrust in the schemes. Small/marginal and landless farmers especially, need to be helped to clearly understand the costs and potential benefits of WII; the key features of the mechanism that trigger pay-outs; and the pay-out amounts, including model uncertainties. In Bihar, blanket approaches to awareness creation (limited to community meetings and the distribution of leaflets and posters) were not sufficient to make less-literate farmers understand the product, nor to access women who lacked literacy and mobility. While they were informed about the trigger points, farmers stated they were unable to remember the process given the complex nature of the product and difficulties in comprehending the knowledge provided. In addition to limited methods of communication, the time the project had to help farmers make sense of the complexities was insufficient. It also demonstrates the necessity of a long-term learning process for both the farmers and the project, which may need to adapt its strategy over time.

In Sirajganj, in contrast, product rollout used a range of media, including posters, leaflets, face-to-face meetings in the villages, videos and street dramas to promote the product. While the more literate farmers could read the printed material, verbal communication (face-to-face discussions in courtyards, mosques and marketplaces; dramas; and especially video) were the most effective with small/marginal and landless farmers, in making them aware of the insurance scheme, and then to help them understand what it offered and how it would operate. Women were reached by holding street dramas and screening videos in places in the community that were accessible to them. Video was the preferred medium across all farmer classes and women for learning about the product. Women could be further targeted, if needed, through separate meetings, as was done to promote a livestock insurance product in Kenya [49].

Even a sound rollout process will not avoid some degree of misunderstanding and negative perceptions after pay-out (where not all insured farmers receive a pay-out). In Sirajganj, it was helpful that the rainfall data was verifiable through the daily newspapers-an independent source of verification for farmers. Where the threshold centers around flood depth and duration, one option may be to install simple and inexpensive flood level monitoring poles at particular points in each village. This would allow the project staff and farmers to monitor the flood scenario and ground verification, contributing to clarity and trust in the product. 
4.2.3. Partnering with a Local NGO/Micro-Finance Institution (MFI) Can Build Trust, Increase Access to Marginal Farmers and Lower Transaction Costs

Institutional credibility emerges as a crucial precondition to attract the more vulnerable male and female farmers especially, to engage in index insurance. Experiences in Bihar and Sirajganj suggest private insurance companies and the unfamiliar WII products are viewed with significant suspicion. Contrasting these two case studies, however, makes clear the difference that partnering with a local MFI can make to farmers' willingness to trust new schemes and actors. Whereas in Bihar, the project used individuals to engage with farmers over a short time period, in the Sirajganj product, implementation was entrusted to an MFI with a long history, deep understanding, extensive network and above all high credibility in the target villages. This helped reach over 7000 farmers across the project's five pilot areas, including some who were landless and some women. In fact, some of the small/marginal farmers interviewed were influenced to purchase insurance because of the trust they had in the MFI.

This trust relationship is especially strong amongst women who also obtained clarifications about the product from the MFI staff. A key advantage of MFIs is that women are a major client base of microfinance, and this can both raise their awareness of the product and potentially help them finance premium payment. NGOs too, may offer critical gender skills, as was the case in the R4 Rural Resilience Initiative (R4 Initiative), which used a specialist NGO service to ensure the insurance aligned with women's needs and circumstances, and to address financial illiteracy through training to help women better understand the product [36]. Furthermore, as seen in Sirajganj, the MFI's permanent presence in the villages and expertise in social mobilization enabled farmer engagement beyond the awareness phase to support differently capacitated farmers to make decisions regarding insurance purchasing and overcome practical obstacles, such as proof of access to land for cultivation by the landless, and support for documentation to farmers more generally. Such support was critical in enabling small/marginal and landless farmers especially, to meet the eligibility criteria.

Especially given the involvement of private companies, balancing social objectives, such as inclusion and cost effectiveness, is important to make these multi-actor partnerships feasible. Insurers who are accustomed to traditional insurance products and marketing modalities may consider index insurance too difficult and expensive to communicate to heterogeneous and varyingly literate populations [50]. In Sirajganj, at the beginning, the project sold the insurance to individual farmers, involving high transaction costs. These costs were reduced when the insurance was routed through the MFI's network. Community-based organizations may also be engaged where these exist, as was the case in the R4 Initiative for engaging women as its target beneficiaries [36].

While partnering with an MFI/local NGO can have a transformative impact on the insurance initiative's ability to balance social objectives with cost, traditional private insurance companies should be provided targeted training to raise their awareness of the social implications of non-inclusive insurance schemes and the complex social contexts in which these social objectives need to be met.

\subsubsection{Building Flexibility into Eligibility Criteria}

Appreciating diverse local realities at the outset will help make criteria more amenable to the diverse conditions and capacities of farmers. Even well-considered criteria will of course present challenges to some farmers, such as the landless and even landed farmers who do not have a copy of land title. Facilitating more sensitive criteria's development and helping farmers navigate criteria is another key role an MFI/local NGO is well positioned to play. In Sirajganj, while the production of a land deed was required, it was applied flexibly in the case of landless farmers where the MFI helped them obtain a photocopy of their respective landlord's title deed, which was deemed sufficient. In each case, the insurance policy was registered in the tenant's name. However, an important risk in this approach is the subjectivity inherent in the landlord-tenant relationship, where some landlords were not willing to support their tenants' purchase of insurance. In Bihar, a similar approach involving a letter from the landlord confirming the tenant is cultivating his land or a copy of the landlord's title failed, as landlords were apprehensive of what legal consequences might arise to their land title. 
In hindsight, a supplementary standard document signed by the tenant, waiving any rights to the land may have made a difference.

Alternatively, other potential methods exist to include the tenant/landless farmers in WII via existing institutions. One option in Bihar (and India) is requesting the village Panchayat (village governance institution) to certify that a particular tenant will cultivate a specified land parcel in a given season. However, this too depends on the willingness of the Panchayat leader to provide his/her endorsement, unless this is made a mandatory function through legislative reform. Other alternatives could be for the MFI/local NGO to certify the area cultivated by a tenant, or the government to instruct the agricultural field officer or other agricultural grassroots officers to authorize the cultivated area and type of crop cultivated by the farmer. This is similar to the practice adopted in India for on-going farmer registration in the government's crop assistance program for disaster-induced damage. Following the exclusion of landless farmers in 2017 in Bihar, IWMI was able to convince the insurance company to include landless farmers through self-declaration of their cultivation in 2018.

\subsubsection{The Affordability of the Premium across Farmer Classes}

This involves ensuring the premium is affordable to all farmer classes, maintaining a profit incentive to private insurers and overcoming the unsustainability of government subsidies in the long term. Nevertheless, in the short term, government subsidies will help farmers invest in agriculture inputs and maintain production, which may convince non-government entities to add their support. This was the case in Bihar where a private seed company has volunteered to subsidize the premium of 200 additional farmers in 2019. (Fisher et al. (2018) [9] acknowledge there may be a moral argument that farmers should not be required to pay an insurance premium to adapt to climate risks, since the poor in developing countries are some of the most heavily impacted by climate change, although they contribute little to its causes).

In the longer term, strategies to increase farmer capacities to pay need to be explored based on what these different farmer classes can reasonably afford. One option could be allowing premiums to be paid in installments either being applicable to all farmers, or to the more marginal groups, including landless and female farmers. MFIs' experiences with micro-insurance show that many small rural households cannot afford to pay premiums upfront, and the preferred solution is a system of weekly or monthly payments by the insured [28]. This could be affected through now-widespread mobile cash transfer technology to minimize additional transaction costs, such as in Kenya [9]. Another possibility is for a development organization to pay the premium to the insurer on behalf of the farmers in lieu of labor (Madajewicz et al., 2017, [51] also see Fisher et al. 2018 [9] for a variation on this theme). Where an MFI is involved, or where savings groups exist, these could provide loans specifically to finance the premium. MFIs could initially pay the premium on behalf of farmers at the rate of interest that only covers any transaction costs incurred by the MFI. Female centered savings/credit groups usually offer BDT 20,000-50,000 (USD 242-605) per person in Bangladesh. The premium of BDT 250 (USD 3) is a fraction of the minimum loan they could take. Implementing the scheme at field level through an MFI could, therefore, potentially link the financing of the insurance premium with self-help groups; for example, by allowing for a special (and very small) loan specifically to enable the low-income households and female farmers to purchase the premium. It is worth noting that if such approaches were to be implemented through a formal bank, the beneficiaries will be predominantly men.

\subsection{A Framework for a Systematic Approach to Inclusive and Equitable Weather Index Insurance Schemes}

Table 4 combines insights from the WII pilots in Bihar and Sirajganj and the literature review into a systematic approach to how future WII could address issues of inclusion and equity. This framework is cognizant of the social equity assessment framework for index insurance presented by Fisher et al. (2018) [9], which presents a set of key aspects to consider with respect to assessing dimensions of social equity, grouping these in terms of equitable access, procedures, representation and distribution. The framework presented below builds on this through a more process-oriented approach, 
making clear that inclusion and equity considerations run through the entire process of WII design, implementation and post-implementation. Indeed, these aspects should influence even the composition of actors involved in WII design and implementation. This framework is thus structured around five primary steps that would broadly constitute the development and implementation of a WII product. In this manner, the framework is meant to help incorporate inclusion and equity considerations from the outset, through the design, implementation and post-payout stages. It emphasizes the centrality of a sound contextual analysis to unpack farmers into landless, marginal/small and large farmer classes, recognizing also, the importance of consistently being sensitive to the specific interests of and challenges faced by women across these farmer classes. It also makes clear that the process does not stop with the insurance payout, since managing unmet expectations of farmers post-payout will be necessary if long-term demand for the product is to occur.

Although applying the suggested framework is likely to involve significant additional up-front costs in the initial years to the insurance program, this investment is expected to increase the accessibility of any WII, and promote a long-term client base. As such, the demand for WII could be expected to increase after the first year, since households will be familiar with the product, and more trusting if the implementation process has been consultative and transparent, potentially offsetting the higher implementation costs in the first year.

Table 4. A process-oriented framework to promote equity in weather index insurance (WII) schemes.

\begin{tabular}{ll}
\hline Steps & Key Considerations \\
\hline Step 1: Team constitution & \\
\hline $\begin{array}{l}\text { Include local partner } \\
\text { institution(s) with appropriate } \\
\text { knowledge, skills and trust in } \\
\text { target communities }\end{array}$ & $\begin{array}{l}\text { These partner(s) will be central to (i) ensuring product design is conscious of } \\
\text { social heterogeneity and includes the more vulnerable farmer classes; (ii) } \\
\text { enderstand the product and prepare all documentation for eligibility, and (iii) } \\
\text { enhance risk management post-payout to ensure misunderstandings do not } \\
\text { undermine the long-term demand for the product. }\end{array}$ \\
\hline
\end{tabular}

\footnotetext{
Step 2: Contextualization and assessment of challenges to developing an inclusive product

Disaggregate male and female farmers into farmer classes (landless, marginal, small, large) to:

Explore correlation between farmer class and vulnerability to climatic risks, and interest in WII

Understand how men and women are able to know about, understand and afford the product

Identify other barriers that may exist amongst each farmer class

Identify local institutions and their de jure and de facto roles, and how these may support or hinder product implementation

$\bigcirc \quad$ Identify any community-based organisations and their activities. Savings groups could help especially marginal men and women purchase insurance.
}

Who are the most vulnerable to weather-induced crop loss/damage, and what are their WII needs?
- Do elevation and other biophysical differences mean some areas are more prone than others?

- What are the characteristics of farmers in these most vulnerable areas e.g., mainly landless/marginal farmers with limited asset bases?

- What are the needs WII needs to cover?
Level of trust in WII products and private insurance schemes, and does this differ between different farmer classes?
- How has prior experience of WII shaped understanding of WII amongst men and women across farmer classes and varying literacy levels?

- $\quad$ Are there discernible differences in willingness to purchase WII between men and women, and between different farmer classes?

- Is there a correlation between willingness to purchase WII and degree of vulnerability? 
Table 4. Cont.

\begin{tabular}{|c|c|}
\hline Steps & Key Considerations \\
\hline & - How many farmers are landless? \\
\hline $\begin{array}{l}\text { How will existing inequalities } \\
\text { affect different farmers' } \\
\text { awareness of a WII product; to } \\
\text { understand it, and to afford it? } \\
\text { How can WII best serve these } \\
\text { groups, including female } \\
\text { farmers? }\end{array}$ & $\begin{array}{l}\text { What are the specific challenges for especially landless and } \\
\text { marginal/small farmers in terms of understanding the product; } \\
\text { meeting eligibility criteria and affording the product? } \\
\text { - Variability in literacy amongst men/women of different farmer classes } \\
\text { - Will mobility prevent women from learning about the WII product? } \\
\text { - How do household dynamics across farmer classes influence decisions on } \\
\text { whether to purchase the WII product? } \\
\text { Where there is out-migration of men, are the women in these households } \\
\text { - } \quad \text { What additional challenges may women headed households face } \\
\text { (e.g., meeting eligibility criteria, filling forms accurately, accessing } \\
\text { information or obtaining signatures from local government, etc.)? }\end{array}$ \\
\hline
\end{tabular}

Step 3: Product development

- How can the WII product be designed make it more understandable?

How can product development respond to the heterogeneous local context (farmer needs and capabilities) while maintaining a business case?
- How can eligibility criteria minimize burdens on the most marginal groups, including landless and women?

- How can payment for the product be made flexible to make it affordable to marginal groups?

- $\quad$ Can the use of mobile transfers be used to minimize transaction costs for the insurer and payout recipients alike?

Step 4: Product implementation

- How can trust in the product be built? E.g.

- Through clear and inclusive communication strategies (see below).

- Providing sufficient time for awareness to be created, recognizing that messages may need to be repeated several times.

$0 \quad$ By training local level leaders about the product and potential benefits, if their word is a source of confidence amongst farmers.

- How can misunderstandings post-payout be minimized, to ensure long-term demand is not undermined?

- All awareness material should clearly emphasize payout trigger points, perhaps using scenarios to make clear the uncertainties involved.

- Explain what data links to the trigger point and how these are collected.

How can product implementation address the challenges that cannot be addressed through product design, especially in relation to landless and marginal men and female farmers?

Explore whether farmers have options to verify all/some of this data

- Make farmers aware of variations in climatic events such as floods across several years, and that the value of insurance is that this variability is covered in the long term.

- What strategies can address differences in literacy? E.g.

$\bigcirc \quad$ Using written, visual and auditory media

- Training local partner staff about the product

- How could landless farmers be assisted if the eligible criteria includes proof of a land title or access to farmland?

- Will landowners verify the lease of their land to their tenants?

- Can village leaders/local government perform this function?

- How can women's lack of mobility be overcome? E.g.

Use communications tools that reach women in the house such as radio, television and social media

Show video or street drama close to the homesteads

Employ female mobilizers who may have greater access to women and be more trusted by women. 
Table 4. Cont.

\begin{tabular}{|c|c|}
\hline Steps & Key Considerations \\
\hline $\begin{array}{l}\text { Which partner will be } \\
\text { responsible for these activities, } \\
\text { and how much time and funds } \\
\text { will be needed? }\end{array}$ & $\begin{array}{l}\text { - Local partners with the necessary social science skills and social networks } \\
\text { should be entrusted with these activities } \\
\text { Implementation will consist of multiple activities, each addressing specific } \\
\text { challenges linked to all or specific farmer classes or women. Realistic time } \\
\text { and budget allocations for each will be essential. }\end{array}$ \\
\hline \multirow{3}{*}{$\begin{array}{l}\text { What roles could local } \\
\text { institutions play in assisting } \\
\text { the implementation process? }\end{array}$} & $\begin{array}{l}\text { Based on the assessment in step } 2 \text { of local government, line agencies and } \\
\text { community-based organizations, explore if: }\end{array}$ \\
\hline & $\begin{array}{l}\text { Local government/village leaders can/will certifying tenancy agreements to } \\
\text { help landless farmers meet eligibility criteria }\end{array}$ \\
\hline & Local savings groups can give loans to its members to buy insurance. \\
\hline \multicolumn{2}{|c|}{ Step 5: Post-payout risk management and adaptation } \\
\hline $\begin{array}{l}\text { What activities will be needed } \\
\text { to assess farmer experiences, } \\
\text { resulting views about the } \\
\text { product and how this may } \\
\text { affect future demand? }\end{array}$ & $\begin{array}{l}\text { Complexity of the product means the risk of misunderstandings and } \\
\text { disappointment amongst farmers who did receive partial/no payout is high. Time } \\
\text { and budget should be set aside for local partners to understand what the issues } \\
\text { are; their root causes, and to develop and implement suitable activities to clarify } \\
\text { these issues. These will likely involve clarifying the manner in which payout is } \\
\text { triggered, and how the payout amount is calculated. }\end{array}$ \\
\hline
\end{tabular}

\section{Conclusions}

The risk that WIIs could deepen existing inequities rather than promote inclusive climate adaptation justifies the question of whether they are the best option for marginal groups, recognizing the myriad of challenges when promoting inclusive WII schemes. These range from the need to balance a business case for private sector partners while minimizing the burden on governments to constantly subsidize WIIs, and the navigation of complex local socio-economic diversity and related political economies. In this context, this paper has attempted to strengthen key messages arising from other evaluations of WII, on how future WII initiatives could minimize their potential to generate negative, unintended consequences.

The two case studies add to the body of existing investigations of WII from the perspective of social equity. As WII schemes proliferate and diversify in focus and structure, critical examination to identify innovations capable of minimizing inequities will be an important function. The case studies from Bihar and Sirajganj demonstrate the diversity of contextual factors influencing access to WIIs, including tenure, literacy, gender and trust in the face of a complex technical product introduced into a heterogeneous human context. The case studies also identify potential strategies to overcome these barriers, and demonstrate through the Sirajganj case study, the multi-faceted benefits of partnering with a local MFI/NGO to address the shortcomings of conventional private insurers with respect to knowledge of and acceptance in local contexts, and the social mobilization skills needed for inclusive implementation, by accounting for the different abilities of farmers to understand the product's potential benefits and how it works, and to meet its eligibility criteria. Reaching marginal groups, including women, require strong local networks and mobilization skills that most private insurance companies lack. Partners with extensive knowledge of rural social structures, institutional capacity, and credibility at the village level are critical to overcome these challenges through a systematic and locally appropriate rollout process. These local partners can also potentially minimize the added transaction costs of such an engaged rollout process, which in fact, could be argued to be an investment that could yield increased demand for the product.

Overall, the case studies and literature review demonstrate that a paramount need is for technical approaches to stop considering farmers as a homogenous group. All actors in product design must further acknowledge their responsibility to ensure unintended, negative consequences are minimized, and commit to process changes that embed product design and implementation in an understanding of the varying situations, capacities, needs and preferences amongst diverse farmers. This can go a 
long way to building farmers' trust and minimizing unrealistic expectations which can undermine product scaling. Given that small/marginal and landless farmers greatly outnumber the richer farmers in Asia, the return on the extra investments to make WII more responsive to their life conditions could be significant. As such, it may be argued that focusing on gender and inclusive development in the WII product enhances the long-term business case, though it needs government and donor support in the initial years to bear the additional costs of more consultative approaches.

These lessons have been used to develop a framework that applies key lessons to several broad steps in the WII development and implementation process. By synthesizing lessons into a framework, this paper makes a significant contribution by promoting a systematic approach for embedding inclusively oriented activities throughout future WII product development and implementation. We propose that this framework be used by donors, governments and private entities funding future WIIs to actively seek more inclusive WII models.

Author Contributions: M.A. and S.d.S. co-prepared the manuscript including the revisions to it. M.A. carried out all primary data collection in Bihar. M.A. and S.d.S. collected primary data in Sirajganj. I.A. undertook the literature review that has been drawn upon to a considerable extent. S.S.-S. guided and supported the framing of the research, the development of data collection tools, contributed to manuscript preparation and the internal review of the paper.

Funding: The research was funded by the Research Programs on Water, Land and Ecosystems (WLE) and Climate Change, Agriculture and Food Security (CCAFS) of the Consultative Group on International Agricultural Research (CGIAR). The CGIAR is a global research partnership for a food-secure future. The APC was funded by Stockholm International Water Institute (SIWI), Sweden.

Acknowledgments: We are grateful to the CGIAR research program on Water, Land and Ecosystems for providing financial support to the case studies conducted in Bihar and Sirajganj. The cooperation and hospitality afforded by the staff of the National Development Program (NDP), and Manab Mukti Sangstha (MMS) in Sirajganj; and the International Network of Alternative Financial Institutions (INAFI) and Institute of Water Modelling (IWM) in Dhaka, who together, greatly facilitated the fieldwork and other logistics. We are also grateful to Giriraj Amaranth and Anoj Kumar of IWMI and the field animators in Bihar for facilitating the Bihar works. A special thanks to Matthew McCartney of IWMI for reviewing the earlier draft of this paper and providing valuable inputs.

Conflicts of Interest: The authors declare no conflict of interest.

\section{References}

1. Bronkhorst, V.B. Disaster Risk Management in South Asia: A Regional Overview; The World Bank: Washington DC, USA, 2012; Available online: http://documents.worldbank.org/curated/en/648281468170977802/pdf/ 763020WP0P11400Box0379791B00PUBLIC0.pdf (accessed on 1 January 2019).

2. IPCC. Climate change 2014: Synthesis report. In Contribution of Working Groups I, II and III to the Fifth Assessment Report of the Intergovernmental Panel on Climate Change; Core Writing Team, Pachauri, R.K., Meyer, L.A., Eds.; IPCC: Geneva, Switzerland, 2014.

3. Ahmad, N. Gender and Climate Change in Bangladesh: The Role of Institutions in Reducing Gender Gaps in Adaptation Program; Social Development Working Papers. Paper No. 126; The World Bank: Washington, DC, USA, 2012.

4. Kelkar, G. The Feminization of Agriculture in Asia: Implications for Women's Agency and Productivity; United Nations Development Fund for Women (UNIFEM) South-Asia Regional Office: New Delhi, India, 2009.

5. Ziervogel, G.; Ericksen, P.J. Adapting to climate change to sustain food security. Adv. Rev. 2010, 1, 525-540. [CrossRef]

6. Nnadi, F.N.; Chikaire, J.; Echetama, J.A.; Ihenacho, R.A.; Umunnakwe, P.C.; Utazi, C.O. Agricultural insurance: A strategic tool for climate change adaptation in the agricultural sector. Net J. Agric. Sci. 2013, 1, $1-9$.

7. Isakson, S.R. Derivatives for development? Small-farmer vulnerability and the financialization of climate risk management. J. Agrar. Chang. 2015, 15, 569-580. [CrossRef]

8. Collins, A. Saying all the right things? Gendered discourse in climate-smart agriculture. J. Peasant Stud. 2018, 45, 175-191. [CrossRef]

9. Fisher, E.; Hellin, J.; Greatrex, H.; Jensen, N. Index insurance and climate risk management: Addressing social equity. Dev. Policy Rev. 2018, 37, 1-22. [CrossRef] 
10. Müller, B.; Johnson, L.; Kreuer, D. Maladaptive outcomes of climate insurance in agriculture. Glob. Environ. Chang. 2017, 46, 23-33. [CrossRef]

11. Roy, A. Poverty Capital: Microfinance and the Making of Development; Routledge: New York, NY, USA, 2010.

12. Greatrex, H.; Hansen, J.W.; Garvin, S.; Diro, R.; Blakeley, S.; Le Guen, M.; Rao, K.N.; Osgood, D.E. Scaling up Index Insurance for Smallholder Farmers: Recent Evidence and Insights; CCAFS Report No. 14; CGIAR Research Program on Climate Change, Agriculture and Food Security (CCAFS): Copenhagen, Denmark, 2015; Available online: https://www.ccafs.cgiar.org (accessed on 1 March 2019).

13. Hazell, P.; Anderson, J.; Balzer, N.; Clemmensen, A.H.; Hess, U.; Rispoli, F. Potential for Scale and Sustainability in Weather Index Insurance for Agriculture and Rural Livelihoods; International Fund for Agricultural Development and World Food Program: Rome, Italy, 2010; Available online: https://www.ifad. org/documents/38714170/40239486/The+potential+for+scale+and+sustainability+in+weather+index+ insurance+for+agriculture+and+rural+livelihoods.pdf/7a8247c7-d7be-4a1b-9088-37edee6717ca (accessed on 1 January 2019).

14. Bryla, E.; Syroka, J. Developing Index-Based Insurance for Agriculture in Developing Countries. United Nations Sustainable Development Innovation Briefs, Issue 2. March 2007. Available online: https: //sustainabledevelopment.un.org/content/documents/no2.pdf (accessed on 1 June 2018).

15. Burke, M.; de Janvry, A.; Quintero, J. Providing Index-Based Agricultural Insurance to Smallholders: Recent Progress and Future Promise; Documento de Trabajo; CEGA University of California at Berkeley: Berkeley, CA, USA, 2010.

16. Johnson, L.; Wandera, B.; Jensen, N.; Banerjee, R. Competing Expectations in an Index-Based Livestock Insurance Project. J. Dev. Stud. 2019, 55, 1221-1239. [CrossRef]

17. Hellin, J.; Fisher, E. Index Insurance, Climate Risk Management and Gender Equality. In The State of Micro Insurance 2018: The Insider's Guide to Understanding the Sector; Micro insurance Annual Journal, 4; The Micro Insurance Network: Luxembourg, 2018; pp. 14-16. Available online: https://microinsurancenetwork.org/ groups/state-microinsurance-2018 (accessed on 1 June 2019).

18. Giné, X.; Townsend, R.; Vickery, J. Patterns of rainfall insurance participation in rural India. World Bank Econ. Rev. 2008, 22, 539-566. [CrossRef]

19. Singh, R.P.K.; Kumar, A.; Singh, K.M.; Kumar, A. Agricultural Production performance on Small farm holdings: Some Empirical Evidences from Bihar, India. Presented at the 8th International Conference of Asian Society of Agricultural Economists (ASAE), Savar, Bangladesh, 15-17 October 2014; Available online: https://mpra.ub.uni-muenchen.de/59680/ (accessed on 1 June 2018).

20. Delavallade, C.; Dizon, F.; Hill, R.V.; Petraud, J.P. Managing Risk with Insurance and Savings: Experimental Evidence from Male and Female Farm Managers in West Africa; Working Paper No. 1426; International Food Policy Research Institute: Washington, DC, USA, 2015; Available online: https://www.poverty-action.org/ sites/default/files/publications/129282.pdf (accessed on 1 January 2019).

21. GOI. All India Report on Agricultural Census of India 2010-11; Agriculture Census Division Department of Agriculture, Cooperation and Farmers Welfare Ministry of Agriculture and Farmers Welfare Government of India, 2015. Available online: http://agcensus.nic.in/document/ac1011/reports/air2010-11complete.pdf (accessed on 1 June 2018).

22. Sugden, F.; Maskey, N.; Clement, F.; Ramesh, V.; Philip, A.; Rai, A. Agrarian stress and climate change in the Eastern Gangetic Plains: Gendered vulnerability in a stratified social formation. Glob. Environ. Chang. 2014, 29, 258-269. [CrossRef]

23. Amarnath, G.; Sikka, A. Satellite data offers new hope for flood-stricken farmers in India. Asia Insurance Review. March 2018, pp. 80-82. Available online: https://www.asiainsurancereview.com/Magazine/ ReadMagazineArticle/aid/40556/Satellite-data-offers-new-hope-for-flood-stricken-farmers-in-India (accessed on 1 January 2019).

24. Matheswaran, K.; Alahacoon, N.; Pandey, R.; Amarnath, G. Flood risk assessment in South Asia to prioritize flood index insurance applications in Bihar, India. Geomat. Nat. Hazards Risk 2019, 10, 26-48. [CrossRef]

25. Aheeyar, M.; de Silva, S.; Sellamuttu, S.S. Pilot evaluation of the Index Based Flood Insurance in Bihar, India: Lessons of Experiences; Technical Report; International Water Management Institute: Colombo, Sri Lanka, 2018; forthcoming. 
26. Aheeyar, M.; de Silva, S.; Sellamuttu, S.S. Experiences from the Second Rollout of the Index Based Flood Insurance in Bihar, India; Technical Report; International Water Management Institute: Colombo, Sri Lanka, 2019; in preparation.

27. Bangladesh Bureau of Statistics. Statistical Year Book Bangladesh 2016; Bangladesh Bureau of Statistics: Dhaka, Bangladesh, 2017.

28. Salman, S.M.; Mahul, O.; Bagazonzya, H.K. Agricultural Insurance in Bangladesh: Promoting Access to Small and Marginal Farmers; The World Bank: Washington, DC, USA, 2010; Available online: http://documents.worldbank.org/curated/en/482331468013812662/Agricultural-insurancein-Bangladesh-promoting-access-to-small-and-marginal-farmers (accessed on 1 December 2017).

29. Das, M.B.; Amin, S.; Johnson, K.; Hossain, A. Whispers to Voices: Gender and Social Transformation in Bangladesh; World Bank: Dhaka, Bangladesh; Washington, DC, USA, 2008.

30. Akhter, A.; Islam, Q.N. Women and Men in Bangladesh: Facts and Figures 2018. Available online: http://bbs.portal.gov.bd/sites/default/files/files/bbs.portal.gov.bd/page/b343a8b4_956b_45ca_872f_ 4cf9b2f1a6e0/Women\%20and\%20men\%20in\%20Bangladesh-Facts\%20and\%20figures\%202018.pdf (accessed on 1 January 2019).

31. EM-DAT. The OFDA/CRED International Disaster Database; Centre for Research on the Epidemiology of Disasters (CRED), Université Catholique de Louvain: Brussels, Belgium, 2015; Available online: http: //www.emdat.be (accessed on 1 June 2018).

32. Clarke, D.J.; Grenham, D. Microinsurance and natural disasters: Challenges and options. Environ. Sci. Policy 2013, 27, 89-98. [CrossRef]

33. Akter, S.; Krupnik, T.J.; Khanam, F. The influence of gender and product design on farmers' preferences for weather-indexed crop insurance. Glob. Environ. Chang. 2016, 38, 217-229. [CrossRef] [PubMed]

34. Patt, A.; Peterson, N.; Carter, M.; Velez, M.; Hess, U.; Suarez, P. Making index insurance attractive to farmers. Mitig. Adapt. Strateg. Glob. Chang. 2009, 14, 737-753. [CrossRef]

35. Eckel, C.C.; Grossman, P.J. Men, women and risk aversion: Experimental evidence. Handb. Exp. Econ. Results 2008, 1, 1061-1073.

36. Miles, K.; Wiedmaier-Pfister, M. Applying a Gender Lens to Climate Risk Finance and Insurance; InsuResilience Global Partnership: Bonn, Germany, 2018.

37. Weber, E.U.; Blais, A.R.E.; Betz, N.E. A domain-specific risk-attitude scale: Measuring risk perceptions and risk behaviors. J. Behav. Decis. Mak. 2002, 15, 263-290. [CrossRef]

38. Binswanger-Mkhize, H.P. Is there too much hype about index-based agricultural insurance? J. Dev. Stud. 2012, 48, 187-200. [CrossRef]

39. Bageant, E.R.; Barrett, C.B. Are There Gender Differences in Demand for Index-Based Livestock Insurance? J. Dev. Stud. 2017, 53, 932-952. [CrossRef]

40. Banthia, A.; Johnson, S.; McCord, M.J.; Mathews, B. Microinsurance that Works for Women: Making Gender Sensitive Micro-Insurance Programs; ILO Micro-Insurance Innovation Facility: Geneva, Switzerland, 2009.

41. Fletschner, D.; Kenney, L. Rural women's access to financial services: Credit, savings, and insurance. In Gender in Agriculture; Springer: Dordrecht, The Netherlands, 2014; pp. 187-208.

42. Hung, A.; Yoong, J.; Brown, E. Empowering Women Through Financial Awareness and Education; OECD Working Papers on Finance, Insurance and Private Pensions, No. 14; OECD Publishing: Paris, France, 2012. [CrossRef]

43. IWMI. Making index-based weather insurance in Bangladesh socially inclusive: Challenges and options. In CGIAR Research Program on Water, Land and Ecosystem; WLE Briefing Series No. 25; International Water Management Institute: Colombo, Sri Lanka, 2019.

44. BMZ; GIZ; IFC; Women's World Bank. Mainstreaming Gender and Targeting Women in Inclusive Insurance: Perspectives and Emerging Lessons: A Compendium of Technical Notes and Case Studies; Deutsche Gesellschaft für Internationale Usammenarbeit (GIZ) GmbH: Bonn, Germany, 2017; Available online: http://documents.worldbank.org/curated/en/229301511502882182/Mainstreaming-gender-and-targetingwomen-in-inclusive-insurance-perspectives-and-emerging-lessons-a-compendium-of-technical-notesand-case-studies (accessed on 1 January 2019).

45. Chiappori, P.A.; Donni, O. Non-Unitary Models of Household Behavior: A Survey of the Literature; IZA Discussion Paper No. 4603; Institute for the Study of Labor: Bonn, Germany, 2009.

46. Zevenbergen, H. Coping with Catastrophes: A Study of Crop Insurances from the Perspective of Small Farmers in India. Master's Thesis, Utrecht University, Utrecht, The Netherlands, 2014. 
47. Akter, S.; Brouwer, R.; Choudhury, S.; Aziz, S. Is there a commercially viable market for crop insurance in rural Bangladesh? Mitig. Adapt. Strat. Glob. Chang. 2009, 14, 215-229. [CrossRef]

48. Akter, S.; Brouwer, R.; van Beukering, P.J.; French, L.; Silver, E.; Choudhury, S.; Aziz, S.S. Exploring the feasibility of private micro flood insurance provision in Bangladesh. Disasters 2011, 35, 287-307. [CrossRef] [PubMed]

49. Khalai, D. Women, Age and Livestock Insurance-A Story from Northern Kenya. 2016. Available online: https://ibli.ilri.org/staff-insights/ (accessed on 1 March 2018).

50. Glaesener-Nasr, J. A debate on: The impact of climate change on microinsurance for smallholder farmers-A debate between Daniel Clarke, Ulrich Hess and Panos Varangis. The State of Microinsurance: Microinsurance Solutions to Address Climate Change. 2017, pp. 24-31. Available online: https://microinsurancenetwork.org/sites/default/files/State\%20of\%20Microinsurance\%202017_ Microinsurance\%20Network.pdf (accessed on 25 October 2018).

51. Madajewicz, M.; Tsegay, A.H.; Lee, R. Managing Risks in Smallholder Agriculture: The Impacts of R4 on Livelihoods in Tigray, Ethiopia from 2012 to 2016; Oxfam External Evaluation Report on the R4 Rural Resilience Initiative (R4); Oxfam America: Washington DC, USA, 2017.

(C) 2019 by the authors. Licensee MDPI, Basel, Switzerland. This article is an open access article distributed under the terms and conditions of the Creative Commons Attribution (CC BY) license (http://creativecommons.org/licenses/by/4.0/). 